
ПОВРЕЖДЕНИЙ ПЕЧЕНИ МЕТОДОМ ГИПОКСИЧЕСКОГО ПРЕКОНДИЦИОНИРОВАНИЯ

\author{
Ходосовский М. Н. (hodosowsky@grsmu.by)
}

УО «Гродненский государственный медицинский университет», Гродно, Беларусь

Введение. Механизм зашчитного эффекта гипоксического прекондиционирования (ГП) при ишемии-реперфузии печени (ИРП) остается недостаточно изученным. Цель работы-изучить вклад монооксида углерода (СО) в механизм защитного действия ГП на печень при ИРП у кроликов.

Материал и методы. 15 взрослых кроликов-самцуов разделили на 2 группьл: в 1-й группе животным выполняли курс ГП и моделировали ИРП в условиях ингибирования гемоксигеназы-1 (ГО-1), во 2-й группе животные дополнительно получали донатор СО. Оиенивались параметры кислородтранспортной функиии (КТФ) крови, продукты перекисного окисления липидов и маркеры повреждения печени (АлАТ, АсАТ).

Результаты. Установлено, что ингибирование ГО-1 при коррекции реперфузионных повреждений печени у кроликов методом ГП приводит к ухудшению КТФ крови и усилению окислительных повреждений органа. Применение донатора СО на фоне ингибирования ГО-1 восстанавливает защитный эффект ГП, препятствуя окислительному стрессу.

Вывод. Механизм защчитного действия ГП при ИРП в большой степени опосредован газотрансмиттерными свойствами СО.

Ключевые слова: гипоксия, печень, гемоксигеназа, реперфузия, кролики

\section{Введение}

Синдром ишемии-реперфузии печени (ИРП) является ведущей причиной ранней дисфункции органа после его резекции или трансплантации [1]. Окислительный стресс, нарушения механизмов транспорта кислорода, воспаление, дисфункция митохондрий являются важнейшими патофизиологическими механизмами повреждений печени после ишемии, которые приводят к гибели клетки органа путем апоптоза или некроза $[2,3]$. Показано, что гипоксическое прекондиционирование (ГП) способно существенно улучшать параметры кислородтранспортной функции (КТФ) крови, прооксидантно-антиоксидантного баланса и функционального состояния печени при ИРП [2]. Однако механизм данного эффекта остается до конца не изученным.

Ранее сообщалось, что у крыс ГП приводит к индукции гемоксигеназы-1 (ГО-1), которая оказывает протективный эффект при ИРП [4]. Известно, что гемоксигеназа (ЕС:1.14.99.3), являясь неотъемлемым клеточным ферментом для всех эукариот, использующих гемопротеины в аэробных процессах окисления, способствует ферментативному распаду гема на биливердин, железо и монооксид углерода (CO) [5]. Однако в настоящее время, антиоксидантные свойства доказаны как для биливердина [6], так и для СО [7].

Цель исследования - изучить вклад монооксида углерода в механизм протективного влияния ГП на печень при моделировании синдрома ее ишемии-реперфузии у кроликов.

\section{Материал и методы}

Работа выполнена на 15 взрослых кроликах-самцах массой 3,5-4,5 кг, предварительно выдержанных в стандартных условиях вивария. Под комбинированным внутривенным наркозом (гексенал 30 мг/кг; калипсол 100 мг/кг) вводили катетеры: один - в v.hepatica для забора печёночной венозной крови, другой - в правое предсердие для получения смешанной венозной крови. Ишемию печени вызывали маневром Прингла - наложением сосудистого зажима на печеночно-двенадцатиперстную связку (Pringle maneuver) в течение 30 минут. После снятия зажима реперфузионный период длился 120 минут. Забор образцов крови для оценки параметров КТФ и ПОЛ крови осуществляли до и после ишемии, а также в конце реперфузионного периода. Функциональное состояние печени оценивали по активности аланин- и аспартатаминотрансфераз (АлАТ и АсАТ) кинетическим методом с помощью стандартного набора реактивов фирмы “Cormay" (Польша). Все оперативные вмешательства осуществляли в условиях адекватной анальгезии в соответствии с нормами, принятыми этической комиссией по гуманному обращению с животными Гродненского государственного медицинского университета.

Животных разделили на 2 экспериментальные группы: в 1-й группе (n=8) животным выполняли курс ГП, после чего моделировали ишемию-реперфузию печени в условиях введения ингибитора ГО-1 - цинк-протопорфирин IX (ZnPP, Sigma, 0,5 мг/кг); во 2-й группе $(\mathrm{n}=7)$ опыты проводили как в 1-й группе, однако за 5 минут до начала реперфузии кролики получали донатор $\mathrm{CO}$, трикарбонилхлоро(глицинат)рутениума(II) - CORM-3 (в/в, 20 мкM/кг). Химический синтез CORM-3 осуществляли по методике Clark J. E. et al. (2003) [8]. С целью ГП животных до эксперимента подвергали трехкратному «подъему» на высоту 3500 м в гипобарической камере, где они находились в течение 1 часа [2].

Ha микрогазоанализаторе Synthesis-15 (Instrumentation Laboratory Company) оценивали параметры КТФ крови: $\mathrm{p}^{-}{ }_{\text {реал }}, \mathrm{pO}_{2}, \mathrm{pCO}_{2}, \mathrm{pH}$, бикарбонат плазмы $\left(\mathrm{HCO}_{3}^{-}\right)$, общиий $\mathrm{CO}_{2}$ плазмы $\left(\mathrm{TCO}_{2}\right)$, действительный избыток оснований (ABE), стандартный избыток оснований (SBE), 
стандартный бикарбонат плазмы (SBC). СГК определяли по показателю p50 (pО крови, соответствующее $50 \%$ насыщению ее кислородом). p50 рассчитывали для стандартных условий $\left(\mathrm{pH}=7,4 ; \mathrm{pCO}_{2}=40\right.$ мм рт. ст. и $\left.\mathrm{T}=37^{\circ} \mathrm{C}\right)$, p50 - рассчитывали для реальных значений этих факторов. Оценку активности процессов перекисного окисления липидов (ПОЛ) проводили по концентрации диеновых конъюгатов (ДК) и оснований Шиффа (ОШ) в плазме крови. Содержание ДК в плазме крови определяли методом ультрафиолетовой спектрофотометрии при длине волны 233 нм [9]. Содержание ОШ определяли по интенсивности флюоресценции хлороформного экстракта при длинах волн возбуждения и эмиссии 344 и 440 нм, соответственно [10].

Статистическую обработку результатов проводили непараметрическими методами. Для оценки достоверности отклонения показателя внутри группы использовали критерий Вилкоксона, между группами - Манна-Уитни (U-тест). Достоверными считали различия при $\mathrm{p}<0,05$.

\section{Результаты и обсуждение}

Влияние ингибирования ГО-1 и введения на этом фоне донатора СО при ГП у кроликов с ИРП на параметры КТФ, ПОЛ и активность трансаминаз печеночной и смешанной венозной крови показано в табл. 1 и 2. Так, на 120-й минуте реперфузии у кроликов 1-й группы в печеночной и смешанной венозной крови по отношению к исходному показателю активность АлАТ увеличивалась в 10,4 (p<0,001) и 10,9 (p<0,001) раза, активность АсАТ возрастала в 9,9 $(\mathrm{p}<0,05)$ и $10,5(\mathrm{p}<0,05)$ раза, соответственно. У животных 2-й группы в конце реперфузионного периода в печеночной и смешанной венозной крови по отношению к кроликам 1-й группы активность АлАТ понижалась на 65,9\% $(\mathrm{p}<0,001)$ и $67,2 \% \quad(\mathrm{p}<0,001)$, соответственно, активность AcАТ уменьшалась - на $62,8 \%(\mathrm{p}<0,001)$ и 71,4 $(\mathrm{p}<0,001)$ раза, соответственно (табл.1 и 2).

Установлено, что в 1-й и 2-й группах моделирование ишемии печени методом Прингла приводило к уменьшению $\mathrm{pO}$ печеночной венозной крови по отношению к исходному уровню на $66,7 \% \quad(p<0,001)$ и 60,6\% (p<0,001), соответственно (табл. 1). В смешанной венозной крови у животных в 1-й и 2-й группах на 30-й минуте ишемии данный показатель снижался менее значительно - на $10,8 \%(\mathrm{p}<0,05)$ и $18,8 \%(\mathrm{p}<0,05)$, соответственно (табл. 2). Одновременно наблюдалось повышение показателя $\mathrm{pCO}_{2}$ по отношению к исходному уровню в крови, оттекающей от печени: в 1-й группе на 102,7\% $(\mathrm{p}<0,05)$, во 2-й группе - на 49,8\% (p<0,05) (табл. 1). В смешанной венозной крови у кроликов 1-й и 2-й групп в конце ишемии показатель $\mathrm{pCO}_{2}$ по отношению к исходному уровню увеличивался на $35,7 \%(\mathrm{p}<0,05)$ и 41,5\% $(\mathrm{p}<0,05)$, соответственно (табл. 2). В конце реперфузионного периода показатель $\mathrm{pO}_{2}$ печеночной венозной крови у кроликов 2-й группы не отличался от исходного, тогда как в 1-й группе $\mathrm{pO}$ оставался ниже на $14,7 \%(\mathrm{p}<0,05)$. Показатель $\mathrm{pCO}_{2}$ печеночной венозной крови в конце реперфузии по отношению к исходному уровню в обеих группах не изменялся (табл. 1). Показатели $\mathrm{pO}_{2}$ и $\mathrm{pCO}_{2}$ смешанной венозной крови на 120-й минуте реперфузии не отличались от исходных (табл. 2).

Параметры кислотно-основного состояния $\mathrm{pH}, \mathrm{HCO}_{3}^{-}, \mathrm{TCO}_{2}, \mathrm{ABE}, \mathrm{SBE}, \mathrm{SBC}-$ у кроликов 1-й и 2-й групп на протяжении ИРП в обоих образцах крови понижались (табл. 1 и 2). Так, на 30 мин. ишемии в 1-й и 2-й группах животных в печеночной венозной крови показатель $\mathrm{HCO}_{3}$ понизился на $31,7 \%(\mathrm{p}<0,05)$ и 29,6\% $(\mathrm{p}<0,05)$, $\mathrm{TCO}_{2}$ - на $22,2 \%(\mathrm{p}<0,05)$ и $26,3 \%(\mathrm{p}<0,05)$, а SBC - на $62,2 \%(\mathrm{p}<0,05)$ и $41,9 \%(\mathrm{p}<0,05)$, соответственно. Схожая динамика изменения данных показателей наблюдалась в смешанной венозной крови обеих групп (табл. 2). В конце реперфузионного периода у животных в 1-й группе в пече-

Tаблица 1. - Показатели кислородтранспортной функции, перекисного окисления липидов и трансаминаз печеночной венозной крови у кроликов (Медиана, нижний квартиль, верхний квартиль (Ме $(25 \% ; 75 \%)$

\begin{tabular}{|c|c|c|c|c|c|c|}
\hline \multirow{2}{*}{ Показатель } & \multicolumn{3}{|c|}{ ZnPP (1-я группа, n=8) } & \multicolumn{3}{|c|}{$\mathrm{ZnPP}+\mathrm{CORM}-3$ (2-я группа, n=7) } \\
\hline & Исходная & 30 мин. ишемии & 120 мин. реперфузии & Исходная & 30 мин. ишемии & 120 мин. реперфузии \\
\hline p50 $\mathbf{p e a n}_{\text {pa }}$, мм.ст. & $32,6(29,8 ; 34,05)$ & $29,8(24,05 ; 35,1)$ & $40,8 *(36,8 ; 42,2)$ & $30,2(29,0 ; 33,9)$ & $30,35(28,8 ; 42,3)$ & $33,8 \#(28,2 ; 37,9)$ \\
\hline p50 & $32,85(31,85 ; 34,6)$ & $14,4 *(12,3 ; 23,75)$ & $30,4 *(30,2 ; 32,2)$ & $31,9(31,1 ; 33,8)$ & $21,55 *(19,5 ; 29,5)$ & $29,3(21,6 ; 33,8)$ \\
\hline Нb, Г/л & $131,5(116 ; 134)$ & $133,5(127 ; 137,5)$ & $122,0(117 ; 124)$ & $130,0(126 ; 137)$ & $127,0(115 ; 131)$ & $124,0(116 ; 127)$ \\
\hline pО, & $37,5(32,0 ; 40,0)$ & $12,5^{*}(10,0 ; 14,0)$ & $32,0 *(28,0 ; 36,0)$ & $33,0(27,0 ; 35,0)$ & $13,0 *(7,0 ; 19,0)$ & $29,0(17,0 ; 41,0)$ \\
\hline рН, ед. & $7,371(7,346 ; 7,468)$ & $6,909 *(6,757 ; 7,069)$ & $7,149 *(7,106 ; 7,294)$ & $7,422(7,393 ; 7,457)$ & $7,110 *(6,758 ; 7,133)$ & $7,245 *(7,032 ; 7,443)$ \\
\hline $\mathbf{p C O}_{2}$, мм рт. ст. & $46,2(38,8 ; 52,05)$ & $93,65 *(75,8 ; 133,0)$ & $54,1(47,1 ; 60,7)$ & $42,8(38,3 ; 48,0)$ & $64,1 *(62,6 ; 101,5)$ & $41,6(37,5 ; 65,5)$ \\
\hline $\mathbf{H C O}_{3}$, ммоль/л & $31,1(29,65 ; 31,45)$ & $21,25 *(18,05 ; 23,05)$ & $19,3 *(18,6 ; 22,6)$ & $29,4(26,4 ; 33,8)$ & $20,7 *(18,4 ; 23,4)$ & $19,4 *(18,3 ; 24,5)$ \\
\hline $\mathbf{T C O}_{2}$, ммоль/л & $32,5(31,0 ; 32,9)$ & $25,3 *(21,9 ; 25,8)$ & $21,2 *(20,2 ; 24,6)$ & $30,8(27,7 ; 35,0)$ & $22,7 *(22,1 ; 26,3)$ & $21,7 *(19,6 ; 25,7)$ \\
\hline АВE, ммоль/л & $6,65(3,9 ; 8,45)$ & $-14,7 *(-19,85 ;-7,1)$ & $-9,2 *(-10,0 ;-3,1)$ & $4,3(1,8 ; 9,6)$ & $-9,3 *(-18,6 ;-7,6)$ & $-8,0 *(-12,5 ; 0,1)$ \\
\hline SBE, ммоль/л & $6,8(4,05 ; 8,25)$ & $-12,55^{*}(-18,35 ;-6,55)$ & $-10,1 *(-10,5 ;-3,9)$ & $4,5(1,3 ; 10,2)$ & $-8,9 *(-17,7 ;-7,6)$ & $-9,2 *(-13,2 ;-0,8)$ \\
\hline SBC, ммоль/л & $29,1(26,7 ; 30,65)$ & $11,0 *(7,25 ; 17,05)$ & $16,1 *(15,8 ; 21,0)$ & $26,7(25,2 ; 31,2)$ & $15,5 *(8,2 ; 16,7)$ & $17,3 *(13,3 ; 24,3)$ \\
\hline ДК, $\Delta \mathrm{E}_{233} / \mathrm{M} Л$ & $0,47(0,38 ; 0,6)$ & $1,49 *(1,25 ; 1,68)$ & $2,11 *(1,93 ; 2,29)$ & $0,56(0,36 ; 0,62)$ & $1,48 *(1,36 ; 1,62)$ & $0,68 \#(0,44 ; 0,76)$ \\
\hline ОШ, ЕД/мЛ & $7,51(7,04 ; 8,13)$ & $10,33 *(9,49 ; 10,89)$ & $11,5^{*}(10,4 ; 11,99)$ & $7,33(7,24 ; 8,56)$ & $9,36 *(9,26 ; 10,37)$ & $8,24 \#(7,66 ; 8,82)$ \\
\hline АлАТ, Ед/л & $30,56(27,94 ; 34,0)$ & $141,43 *(122,2 ; 178,96)$ & $317,77 *(295,9 ; 412,9)$ & $29,68(24,44 ; 34,9)$ & $164,12 *(143,2 ; 181,6)$ & $108,25^{*} \#(73,33 ; 129,2)$ \\
\hline АсAТ, Ед/л & $34,05(30,6 ; 35,79)$ & $174,6 *(167,6 ; 195,6)$ & $337,85^{*}(316,9 ; 412,9)$ & $36,67(33,17 ; 38,4)$ & $150,16 * \#(124,0 ; 167,6)$ & $125,7 * \#(85,55 ; 143,2)$ \\
\hline
\end{tabular}

Примечание: ZnPP - цинк протопорфирин IX (ингибитор гемоксигеназы-1), СОRМ-3 - молекула, высвобождающая монооксид углерода. Достоверное различие $(p<0,05)$ по отношению к: * - исходному уровню в своей группе; \# - к соответствуюшему периоду в 1-й группе 
ночной венозной крови показатели $\mathrm{HCO}_{3}^{-}, \mathrm{TCO}_{2}$ и $\mathrm{SBC}$ были ниже исходного уровня на $37,9 \%$ $(\mathrm{p}<0,05), 34,8 \%(\mathrm{p}<0,05)$ и 44,7\% $(\mathrm{p}<0,05)$, во 2-й группе - на 34,0\% $(\mathrm{p}<0,05), 29,5 \%(\mathrm{p}<0,05)$ и $35,2 \%(p<0,05)$, соответственно. В смешанной венозной крови на 120 -й минуте реперфузии у животных обеих групп наблюдалась схожая динамика снижения показателей $\mathrm{HCO}_{-}$, $\mathrm{TCO}_{2}$ и $\mathrm{SBC}$ (табл. 2).

В конце ишемического периода у кроликов 1-й и 2-й групп наблюдалось уменьшение $\mathrm{p} 50_{\text {станд }}$ на $56,2 \%(\mathrm{p}<0,05)$ и $32,4 \%(\mathrm{p}<0,05)$ в печеночной венозной крови, соответственно, тогда как показатель р50 неал не изменялся (табл. 1). В конце ишемии у животных в 1-й и 2-й группах в смешанной венозной крови $\mathrm{p} 50$ был выше исходного на $32,3 \%(\mathrm{p}<0,05)$ и $28,3 \%(\mathrm{p}<0,05)$, соответственно. Установлено, что в конце реперфузии $\mathrm{p} 50_{\text {реал }}$ у животных 1-й группы оставался повышенным в печеночной и смешанной венозной крови на 25,2\% $(\mathrm{p}<0,05)$ и $22,7 \%(\mathrm{p}<0,05)$, соответственно. У кроликов 2-й группы на 120-й минуте реперфузии уровень р50 веал в печеночной венозной крови не отличался от исходного, в смешанной - повышался на 18,7\% $(\mathrm{p}<0,05)$. При этом в обоих образцах венозной крови у животных 2-й группы показатель р50 реал был ниже, чем у кроликов 1-й группы в конце реперфузионного периода (табл. 1 и 2).

Ингибирование ГО-1 у кроликов 1-й группы приводило к росту содержания продуктов ПОЛ в обоих образцах венозной крови (табл. 1 и 2). Так, уровень ДК в печеночной и смешанной венозной крови в коне реперфузии повышался в 4,5 (p<0,001) и 5,4 (p<0,001) раза, ОШ - в $1,5(\mathrm{p}<0,05)$ и $1,4(\mathrm{p}<0,05)$ раза, соответственно. Инфузия донатора CO - CORM-3 перед началом реперфузионного периода способствовала снижению продуктов ПОЛ в плазме печеночной и смешанной венозной крови у кроликов 2-й группы по отношению к животным 1-й группы (табл. 1 и 2). Так, показатель ДК в печеночной и смешанной венозной крови в конце реперфузии снижался по отношению к 1-й группе на $67,8 \%$ $(\mathrm{p}<0,001)$ и 71,8\% $(\mathrm{p}<0,001)$, ОШ - на $28,3 \%$ $(\mathrm{p}<0,05)$ и $27,9 \%(\mathrm{p}<0,05)$, соответственно. Важно отметить, что у животных во 2-й группе уровни ДК и ОШ в обоих образцах крови в конце реперфузии не отличались от исходных значений (табл. 1 и 2).

Установлено, что при ИРП у кроликов 1-й группы наблюдалось развитие метаболического ацидоза (судя по показателям $\mathrm{pH}, \mathrm{ABE}, \mathrm{SBE}$ и $\mathrm{SBC})$. Повышение показателя $\mathrm{pCO}_{2}$ в печеночной венозной крови могло быть следствием застойных явлений и нарушения микроциркуляции в печени. Снижение СГК крови у животных в 1-й группе при ИРП (судя по росту показателя p50 ) сопровождалось повышением активности процессов ПОЛ (увеличение ДК и ОШ) и повреждением ими мембранных структур клеток печени, что приводило к многократному росту активности трансаминаз крови (АлАТ и АсАТ). Результаты, полученные у животных 1-й группы, согласуются с данными работы [4], в которой установили снижение протективного эффекта ГП при ингибировании ГО-1 с помощью ZnPP по уровню АлАТ. По-видимому, снижение СГК крови и увеличение потока $\mathrm{O}_{2}$ в ткани в начале реперфузии в 1-й группе способствовало усилению окислительных повреждений печени вследствие значительного нарушения редокс-состояния митохондрий [11]. Показано, что повышение проницаемости мембран митохондрий под влиянием окислительного стресса при ИРП приводит к гибели гепатоцитов путем некроза или апоптоза [12].

Известно, что ишемия/Гипоксия является

Tаблица 2. - Показатели кислородтранспортной функции, перекисного окисления липидов и трансаминаз смешанной венозной крови у кроликов (Медиана, нижний квартиль, верхний квартиль $($ Ме $(25 \% ; 75 \%))$

\begin{tabular}{|c|c|c|c|c|c|c|}
\hline \multirow{2}{*}{ Показатель } & \multicolumn{3}{|c|}{ ZnPP (1-я группа, n=8) } & \multicolumn{3}{|c|}{ ZnPP + CORM-3 (2-я группа, n=7) } \\
\hline & Исходная & 30 мин ишемии & 120 мин реперфузии & Исходная & 30 мин ишемии & 120 мин реперфузии \\
\hline p50 & $32,55(30,3 ; 36,0)$ & $43,05 *(40,05 ; 44,35)$ & $39,95 *(37,05 ; 41,25)$ & $29,9(29,4 ; 33,3)$ & $38,35 *(36,5 ; 44,3)$ & $35,5^{*} \#(32,4 ; 36,3)$ \\
\hline p50 $\mathbf{c r a а н , ~}_{1}$ мм рт.ст. & $33,6(32,2 ; 34,3)$ & $30,3(27,95 ; 31,95)$ & $31,45 *(29,7 ; 32,4)$ & $32,2(30,5 ; 34,8)$ & $29,1 *(27,9 ; 31,9)$ & $29,3(28,1 ; 33,7)$ \\
\hline $\mathbf{H b}$, г/л & $123,0(117,5 ; 131,5)$ & $124,0(113,5 ; 129,5)$ & $119,5(115 ; 125)$ & $126,0(110 ; 129)$ & $124,0(101 ; 129)$ & $128,0(116 ; 129)$ \\
\hline $\mathbf{p O}_{2}$, мм рт. ст. & $32,5(29,5 ; 35,0)$ & $29,0 *(25,0 ; 31,5)$ & $27,0(25,0 ; 32,5)$ & $32,0(26,0 ; 34,0)$ & $26,0 *(22,0 ; 28,0)$ & $25,0(22,0 ; 39,0)$ \\
\hline pH, ед. & $7,419(7,302 ; 7,451)$ & $7,114 *(6,998 ; 7,210)$ & $7,218 *(7,140 ; 7,281)$ & $7,432(7,401 ; 7,452)$ & $7,174 *(6,994 ; 7,294)$ & $7,268 *(7,138 ; 7,363)$ \\
\hline $\mathbf{p C O}_{2}$, мм рт. ст. & $45,9(41,95 ; 54,35)$ & $62,3 *(56,1 ; 74,9)$ & $49,45(45,3 ; 60,4)$ & $39,0(38,2 ; 48,3)$ & $55,2 *(44,9 ; 71,7)$ & $43,6(42,1 ; 59,6)$ \\
\hline $\mathrm{HCO}_{3}^{-}$, ммоль/л & $30,35(27,75 ; 32,35)$ & $21,35 *(19,9 ; 22,7)$ & $20,65 *(18,1 ; 22,9)$ & $26,4(26,2 ; 32,1)$ & $20,0 *(17,2 ; 24,3)$ & $20,4 *(18,2 ; 24,5)$ \\
\hline $\mathbf{T C O}_{2}$, ммоль/л & $31,85(29,35 ; 33,65)$ & $23,65^{*}(21,95 ; 24,55)$ & $22,4 *(19,5 ; 24,25)$ & $27,5(27,5 ; 33,7)$ & $21,2 *(18,8 ; 26,3)$ & $22,3 *(19,5 ; 25,8)$ \\
\hline ABE, ммоль/л & $5,75(1,45 ; 8,6)$ & $-7,8 *(-11,4 ;-5,8)$ & $-6,55 *(-9,8 ;-3,45)$ & $3,1(2,5 ; 6,7)$ & $-7,4 *(-13,2 ;-4,6)$ & $-6,6 *(-8,5 ;-0,4)$ \\
\hline SBE, ммоль/л & $5,6(1,7 ; 8,65)$ & $-8,0 *(-11,35 ;-5,95)$ & $-7,55 *(-10,5 ;-3,85)$ & $2,2(1,5 ; 7,1)$ & $-8,0^{*}(-14,0 ;-4,4)$ & $-7,7 *(-9,6 ;-1,3)$ \\
\hline SBC, ммоль/л & $28,35(24,6 ; 30,55)$ & $17,05 *(14,45 ; 18,65)$ & $18,4 *(15,6 ; 20,7)$ & $25,9(25,6 ; 28,6)$ & $17,4 *(13,1 ; 19,4)$ & $18,0 *(16,3 ; 23,7)$ \\
\hline ДК, $\Delta \mathrm{E}_{233} / \mathrm{M} Л$ & $0,42(0,38 ; 0,55)$ & $1,2 *(1,01 ; 1,41)$ & $2,27 *(1,86 ; 2,6)$ & $0,52(0,42 ; 0,6)$ & $1,42 *(1,14 ; 1,58)$ & $0,64 \#(0,5 ; 0,84)$ \\
\hline ОШ, ЕД/мл & $7,9(7,46 ; 8,33)$ & $10,22 *(9,27 ; 10,9)$ & $11,4 *(10,84 ; 12,19)$ & $7,28(7,21 ; 8,48)$ & $9,74 *(9,17 ; 10,22)$ & $8,22 \#(7,38 ; 8,71)$ \\
\hline АлАТ, Ед/л & $29,68(27,06 ; 34,05)$ & $144,92 *(123,1 ; 178,1)$ & $324,76 *(293,3 ; 410,3)$ & $29,68(24,44 ; 34,9)$ & $150,2 *(120,5 ; 158,9)$ & $106,51 * \#(90,79 ; 129,2)$ \\
\hline АсАТ, ЕД/л & $31,43(31,4 ; 35,79)$ & $166,74 *(154,5 ; 185,95)$ & $329,99 *(307,3 ; 401,6)$ & $34,92(31,43 ; 36,7)$ & $143,17 *(117,0 ; 160,6)$ & $94,28 * \#(80,32 ; 132,7)$ \\
\hline
\end{tabular}

Примечание: ZnPP - цинк протопорфирин IX (ингибитор гемоксигеназы-1), CORM-3 - молекула, высвобождающая монооксид углерода. Достоверное отличие $(p<0,05)$ по отношению к: * - исходному уровню в своей группе; \#- к соответствующему периоду в 1-й группе 
главным условием, препятствующим деградации гипоксией индуцированного фактора-1-альфа (ГИФ-1a), который вызывает запуск многих защитных механизмов при ишемии-реперфузии $[13,14]$. Очевидно, что снижение СГК крови и повышение потока $\mathrm{O}_{2}$ в ткани способствовало ускорению гидроксилирования ГИФ-1а в реперфузионном периоде. Последнее могло нивелировать независимые от ГО-1 пути протекции ГИФ1a, что приводило к реперфузионным повреждениям печени у экспериментальных животных 1-й группы (судя по АлАТ и АсАТ). Вместе с тем известна способность ГО-1 стабилизировать работу митохондрий, препятствовать воспалению и апоптозу за счет антиоксидантных эффектов СО и биливердина при ИРП [15]. Чтобы исключить антиоксидантные эффекты билирубина или биливердина при активации ГО-1, вызванной ГП, во 2-й группе животных на фоне ингибирования ГО-1 проводили инфузию донатора CO (CORM-3).

Выявлено, что ранее установленный защитный эффект ГП при ИРП [2] практически полностью восстанавливается у кроликов 2-й группы (судя по активности процессов ПОЛ, АЛАТ и AcАТ). Изменения р50 уеал у животных 2-й группы указывают на повышение СГК крови в конце реперфузии по отношению к кроликам 1-й группы, что может быть фактором лимитирования активности ПОЛ и окислительных повреждений (судя по изменению ДК и ОШ). Повышение СГК печеночной венозной крови при реперфузии печени может быть одним из механизмов, препятствующих деградации гипоксией индуцированного ГИФ-1a, с активностью которого связы-

\section{Литература}

1. Predictive factors of short term outcome after liver transplantation / G. Bolondi [et al.] // World J. Gastroenterol. - 2016. - № 26. - P. 5936-5949.

2. Ходосовский, М. Н. Влияние гипоксического прекондиционирования на механизмы транспорта кислорода и окислительные повреждения при синдроме ишемии-реперфузии печени у кроликов / М. Н. Ходосовский // Физиологический журнал. - 2016. - Т. 62, № 3. - С. 39-47.

3. Datta, G. Molecular mechanisms of liver ischemia reperfusion injury: insights from transgenic knockout models / G. Datta, B. J. Fuller, B. R. Davidson // World J. Gastroenterol. - 2013. - Vol. 19, № 11. - P. 1683-1698.

4. The protective role of heme oxygenase- 1 on the liver after hypoxic preconditioning in rats / I. R. Lai [et al.] // Transplantation. - 2004. - Vol. 77, № 7. - P. 1004-1008.

5. Ischemic preconditioning protects against liver ischemia/ reperfusion injury via heme oxygenase-1-mediated autophagy / A. Liu [et al.] // Critical Care Medicine. 2014. - Vol. 42, № 12. - P. e762-e771.

6. Therapeutic applications of bilirubin and biliverdin in transplantation / R. Ollinger [et al.] // Antioxid. Redox Signal. - 2007. - Vol. 9, № 12. - P. 2175-2185.

7. Carbon monoxide has antioxidative properties in the liver involving p38 MAP kinase pathway in a murine model of systemic inflammation / J. Brugger [et al.] // Microcirculation. - 2010. - Vol. 17, № 7. - P. 504-513.

8. Cardioprotective actions by a water-soluble carbon вают индукцию таких защитных эффектов при ИРП, как противовоспалительный, антиапоптотический и антиоксидантный [13]. Показано, что ГИФ-1а способен улучшать функцию митохондрий гепатоцитов и снижать продукцию активных форм кислорода при ИРП [14]. Известно, что СО является мощным цитопротектором при сердечно-сосудистых заболеваниях, при сепсисе и шоке, трансплантации органов, острых поражениях легких, почек и печени [16]. СО в малых дозах может проявлять антиокислительную активность путем активации генов антиоксидантных ферментов [17]. Таким образом, газотрансмиттерные свойства СО вносят существенный вклад в эффективность гипоксического прекондиционирования при ИРП.

\section{Выводы}

1. Ингибирование гемоксигеназы-1 при коррекции реперфузионных повреждений печени у кроликов методом гипоксического прекондиционирования приводит к ухудшению кислородсвязывающих свойств крови и усилению окислительных повреждений органа.

2. Применение донатора СО на фоне ингибирования гемоксигеназы-1 восстанавливает защитный эффект гипоксического прекондиционирования, препятствуя нарушениям механизмов транспорта кислорода и окислительному стрессу.

Автор выражает благодарность доценту кафедры общей и биоорганической химии ГрГМУ Бубену Александру Леонидовичу

за техническое содействие в химическом синтезе CORM-3.

monoxide-releasing molecule / J. E. Clark [et al.] // Circ. Res. - 2003. - Vol. 93, № 2. - P. e2-e8.

9. Гаврилов, В. Б. Измерение диеновых конъюгатов в плазме крови по УФ-поглощению гептановых и изопропанольных экстрактов / В. Б. Гаврилов, А. Р. Гаврилова, А. Ф. Хмара // Лабораторное дело. - 1988. - № 2. - C. 60-64.

10. Fletcher, B. L. Measurement of fluorescent lipid peroxidation products in biological systems and tissues / B. L. Fletcher, C. J. Dillard, A. L. Tappel // Anal. Biochem. - 1973. - Vol. 52, № 1. - P. 1-9.

11. Mitochondrial Dysfunction and Autophagy in Hepatic Ischemia/Reperfusion Injury / K. L. Go [et al.] // Biomed. Res. Int. - 2015. - Vol. 2015. doi: 10.1155/2015/183469.

12. Kim, J. S. Mitochondrial permeability transition in rat hepatocytes after anoxia/reoxygenation: role of $\mathrm{Ca} 2+-$ dependent mitochondrial formation of reactive oxygen species / J. S. Kim, J. H. Wang, J. J. Lemasters // Am. J. Physiol. Gastrointest. Liver Physiol. - 2012. - Vol. 302, № 7. - P. G723-G731.

13. Loss or silencing of the PHD1 prolyl hydroxylase protects livers of mice against ischemia/reperfusion injury / $\mathrm{M}$. Schneider [et al.] // Gastroenterology. - 2010. - Vol. 138, № 3. - P. 1143-1154.

14. Activation of the oxygen-sensing signal cascade prevents mitochondrial injury after mouse liver ischemiareperfusion / Z. Zhong [et al.] // Am. J. Physiol. Gastrointest. Liver Physiol. - 2008. - Vol. 295, N 4. P. G823-G832.

15. Liu, B. Cytoprotective role of heme oxygenase-1 in liver 
ischemia reperfusion injury / B. Liu, J. M. Qian // Int. J. Clin. Exp. Med. - 2015. - Vol. 8, № 11. - P. 19867-19873.

16. Bauer, I. Bench-to-bedside review: Carbon monoxidefrom mitochondrial poisoning to therapeutic use / I Bauer, B. H. Pannen // Crit. Care. - 2009. - Vol. 13, № 4. - P. 220.

17. $\mathrm{CO} / \mathrm{HO}-1$ Induces NQO-1 Expression via Nrf2 Activation / H. J. Kim [et al.] // Immune Netw. - 2011. - Vol. 11, № 6. - P. 376-382.

\section{References}

1. Bolondi G, Mocchegiani F, Montalti R, Nicolini D, Vivarelli M, De Pietri L. Predictive factors of short term outcome after liver transplantation. World $J$. Gastroenterol. 2016;26:5936-5949.

2. Khodosovsky MN. Vlijanie gipoksicheskogo prekondicionirovanija na mehanizmy transporta kisloroda i okislitel'nye povrezhdenija pri sindrome ishemii-reperfuzii pecheni u krolikov. [Influence of hypoxic preconditioning on the mechanisms of blood oxygen transport and oxidative damages during hepatic ischemia-reperfusion in rabbits]. Fiziologicheskij zhurnal. 2016;62(3):39-47. (Russian).

3. Datta G, Fuller BJ, Davidson BR. Molecular mechanisms of liver ischemia reperfusion injury: insights from transgenic knockout models. World J. Gastroenterol. 2013;19(11):1683-1698.

4. Lai IR, Ma MC, Chen CF, Chang KJ. The protective role of heme oxygenase-1 on the liver after hypoxic preconditioning in rats. Transplantation. 2004;77(7):1004-1008.

5. Liu A, Fang H, Wei W, Dirsch O, Dahmen U. Ischemic preconditioning protects against liver ischemia/reperfusion injury via heme oxygenase-1-mediated autophagy. Critical Care Medicine. 2014;42(12):e762-e771.

6. Ollinger R, Wang H, Yamashita K, Wegiel B, Thomas M, Margreiter R, et al. Therapeutic applications of bilirubin and biliverdin in transplantation. Antioxid. Redox Signal. 2007;9(12):2175-2185

7. Brugger J, Schick MA, Brock RW, Muellenbach RM, Roewer N, Wunder C, et al. Carbon monoxide has antioxidative properties in the liver involving p38 MAP kinase pathway in a murine model of systemic inflammation. Microcirculation. 2010;17(7):504-513.

8. Clark JE, Naughton P, Shurey S, Green CJ, Johnson TR, Mann BE, et al. Cardioprotective actions by a water-soluble carbon monoxide-releasing molecule. Circ. Res. 2003;93(2):e2-e8.

9. Gavrilov VB, Gavrilova AR, Hmara AF. Izmerenie dienovyh konjugatov v plazme krovi po UF-pogloshheniju geptanovyh i izopropanol'nyh jekstraktov. [Measurement of diene conjugates in blood plasma using the UV absorption of heptane and isopropanol extracts]. Laboratornoe delo. 1988;2:60-64. (Russian).

10. Fletcher BL, Dillard CJ, Tappel AL. Measurement of fluorescent lipid peroxidation products in biological systems and tissues. Anal. Biochem. 1973;52(1):1-9.

11. Go KL, Lee S, Zendejas I, Behrns KE, Kim J-S. Mitochondrial Dysfunction and Autophagy in Hepatic Ischemia/Reperfusion Injury. Biomed. Res. Int. 2015;2015. doi: $10.1155 / 2015 / 183469$.

12. Kim JS, Wang JH, Lemasters JJ. Mitochondrial permeability transition in rat hepatocytes after anoxia/reoxygenation: role of $\mathrm{Ca} 2+$-dependent mitochondrial formation of reactive oxygen species. Am. J. Physiol. Gastrointest. Liver Physiol. 2012;302(7):G723-G731.

13. Schneider M, Van Geyte K, Fraisl P, Kiss J, Aragones J, Mazzone M, et al. Loss or silencing of the PHD1 prolyl hydroxylase protects livers of mice against ischemia/ reperfusion injury. Gastroenterology. 2010;138(3):11431154.

14. Zhong Z, Ramshesh VK, Rehman H, Currin RT, Sridharan V, Theruvath TP, Kim I, Wright GL, Lemasters JJ. Activation of the oxygen-sensing signal cascade prevents mitochondrial injury after mouse liver ischemia-reperfusion. Am. J. Physiol. Gastrointest. Liver Physiol. 2008;295(4):G823-G832.

15. Liu B, Qian JM. Cytoprotective role of heme oxygenase-1 in liver ischemia reperfusion injury. Int. J. Clin. Exp. Med. 2015;8(11):19867-19873.

16. Bauer I, Pannen BH. Bench-to-bedside review: Carbon monoxide-from mitochondrial poisoning to therapeutic use. Crit. Care. 2009;13(4):220.

17. Kim HJ, Zheng M, Kim S-K, Cho JJ, Shin CH, Joe Y, Chung HT. CO/HO-1 Induces NQO-1 Expression via Nrf2 Activation. Immune Netw. 2011;11(6):376-382.

\title{
CONTRIBUTION OF CARBON MONOXIDE TO CORRECTION OF HEPATIC REPERFUSION DAMAGES BY MEANS OF HYPOXIC PRECONDITIONING METHOD
}

\author{
Khodosovsky M. N.
}

Educational Institution "Grodno State Medical University", Grodno, Belarus

Background. The mechanism of hypoxic preconditioning (HP) protection in hepatic ischemia-reperfusion (HIR) remains unclear. The aim of the study was to examine the role of carbon monoxide (CO) in HP protection during HIR in rabbits.

Material and methods. 15 adult male rabbits were divided into 2 groups: in the 1st group HIR was performed after the course of HP and hemoxygenase-1 (HO-1) inhibition, in the 2nd group the animals were handled like in the 1st group, but additionally they were given $C O$ donor. The parameters of blood oxygen (BO), lipid peroxidation products and markers of liver damage (ALAT, ASAT) were evaluated.

Results. It was found that HO-1 inhibition during the correction of hepatic reperfusion damage by means of HP in rabbits leads to worsened $\mathrm{BO}$ and increased oxidative damages of the organ. The use of a CO donor during HO-1 inhibition restores the protective effect of $H P$, preventing oxidative stress.

Conclusion. The mechanism of the protection by means of HP during HIR is to a large extent mediated by gasotransmitter properties of $\mathrm{CO}$.

Keywords: hypoxia, liver, hemoxygenase, reperfusion, rabbits 